Bond University ePublications@bond

Sports Law eJournal

Faculty of Law

2-23-2015

\title{
Copyright and Sport Broadcasting in Australia and England
}

Chris Davies

Follow this and additional works at: http://epublications.bond.edu.au/slej

Part of the Entertainment, Arts, and Sports Law Commons

Recommended Citation

Chris Davies. (2015) "Copyright and Sport Broadcasting in Australia and England" , : ISSN 1836-1129.

http://epublications.bond.edu.au/slej/26

This Journal Article is brought to you by the Faculty of Law at ePublications@bond. It has been accepted for inclusion in Sports Law eJournal by an authorized administrator of ePublications@bond. For more information, please contact Bond University's Repository Coordinator. 


\title{
Copyright and Sport Broadcasting in Australia and England
}

\author{
Abstract \\ Television rights are an essential component of the revenue generated by professional sporting leagues, and \\ protecting the copyright in the broadcasting of matches is therefore of significant importance to these leagues. \\ A Federal Court decision has held that there had been in breach of copyright when Optus allowed its mobile \\ phone users to access matches on a two minute delay. However, European and English Courts have held that \\ the plaintiff's copyright only existed in the anthem, graphics and recorded highlights, not in the actual \\ matches.
}

\section{Keywords}

Copyright, broadcasting, pro sports leagues, NRL, AFL, Singtel Optus v NRL Investments Pty Ltd (No. 2) 2012

\section{Disciplines}

Entertainment, Arts, and Sports Law 


\title{
COPYRIGHT AND SPORT BROADCASTING IN AUSTRALIA AND ENGLAND
}

\author{
CHRIS DAVIES*
}

\begin{abstract}
Television rights are an essential component of the revenue generated by professional sporting leagues, and protecting the copyright in the broadcasting of matches is therefore of significant importance to these leagues. A Federal Court decision has held that there had been in breach of copyright when Optus allowed its mobile phone users to access matches on a two minute delay. However, European and English Courts have held that the plaintiff's copyright only existed in the anthem, graphics and recorded highlights, not in the actual matches.
\end{abstract}

\section{INTRODUCTION}

Broadcasting rights have been an important component of sport revenue for many decades, and in Australia it was only the advent of pay television rights that allowed the main football codes to go fully professional in the mid-1990s. While English soccer has been full time professional for well over a hundred years it was the now $16 \mathrm{~b}$ exclusive television rights from pay television network, Sky, that saw the English Premier League (EPL) grow into arguably the best league in Europe. However, the value of these lucrative and essential television rights was potentially placed in jeopardy by, in Australia, the actions of Optus in providing a means for its mobile phone users to watch matches on a two minute delay, and in England, by pub owners showing EPL matches to customers without paying a commercial licence fee. With much at stake it was not surprising that legal action was taken in both instances.

This paper will examine the situation, and the subsequent legal cases, in both the National Rugby League (NRL) ${ }^{1}$ and the EPL. ${ }^{2}$ This will involve examining the alleged breaches of copyright, and in regard to the NRL, the interpretation of the relevant amendments of the Copyright Act 1968 (Cth) and its potential impact on professional sport in Australia. Whether sport in Australia is its own industry or part of a broader entertainment industry will also be considered. First, however, it will briefly examine the relevant 2006 amendments to the Copyright Act.

\section{THE 2006 AMENDMENTS TO THE COPYRIGHT ACT}

A feature of the Copyright Act when it was enacted in 1968 was that, while vesting in the owner exclusive control over the reproduction and broadcasting of the subject matter, it only extended copyright protection to known methods of reproduction. This created potential future problems, as amendments could be needed to ensure that, with the introduction of new technologies,

* Associate Professor, School of Law, James Cook University.

$1 \quad$ Singtel Optus v National Rugby League Investments Pty Ltd (No2) [2012] FCA 34; National Rugby League Investments Pty Ltd v Singel Optus Pty Ltd [2012] FCAFC 59 (NRL v Optus).

2 Football Association Premier League Ltd (FAPL) v QC Leisure [2012] 2 CMLR 514; [2012] EWHC 108 (Ch); Murphy v Media Protection Services Ltd (No 1) [2012] 3 CMLR 41. 
copyright control still remained vested with the owner. ${ }^{3}$ It was a problem that was solved by amendments in 2000, which introduced 'technology-neutral right of communication to the public which replaced technology-specific dissemination rights.' ${ }^{3}$ This now meant copyright protection applied to any conceivable form of disseminating copyright material ${ }^{5}$ with further amendments being made by the Copyright Amendment Act 2006 (Cth). ${ }^{6}$

It was acknowledged in the Explanatory Memorandum to the 2006 Bill that time shifting recording had been around since the use of video cassette recorders in the 1970s, the present day use simply being more advanced. ${ }^{7}$ The 2006 Act therefore introduced five new defences into s 68CA to allow very limited time and format shifting of limited copyright material for private and domestic use, including allowing the time shifting of broadcasts under s 111. ${ }^{8}$ This amended $\mathrm{s}$ 111(1) now applied if a person makes a cinematographic film or sound broadcast solely for private or domestic use' to watch or listen 'at a time more convenient than the time when the broadcast is made.' Sub-section 2 then stated that such use does not infringe copyright of the broadcast. The Explanatory Memorandum also noted that copying for personal use was particularly popular in two areas, namely, time-shifting and format shifting, ${ }^{9}$ and that these practices would be likely to have 'negligible market impact'. ${ }^{10}$

It was these arrangements of being able to record and then watch a broadcast later at a more convenient time that became the subject of the litigation involving Optus and the major sports within Australia.

\section{THE NATIONAL RUGBY LEAGUE}

\section{Background facts}

In July 2011, Singtel Optus and its subsidiary, Optus Mobile Pty Ltd, ${ }^{11}$ began a new service called TV Now enabling customers to record free to air television programmes on personal computers, iPhone or iPod, Android mobile devices, or $3 \mathrm{G}$ mobile phones. ${ }^{12}$ The central issue in the case was whether Optus had infringed copyright of the NRL, Australian Football League (AFL) and Telstra in regard to a number of matches played in September 2011.13 The parties agreed that copyright subsided in each of the NRL and AFL broadcasts and films and that the NRL and AFL owned the respective copyright to these, while Telstra was the exclusive licensee of the copyright in regard to internet and mobile phone use. ${ }^{14}$ The alleged copyright breaches centred on whether

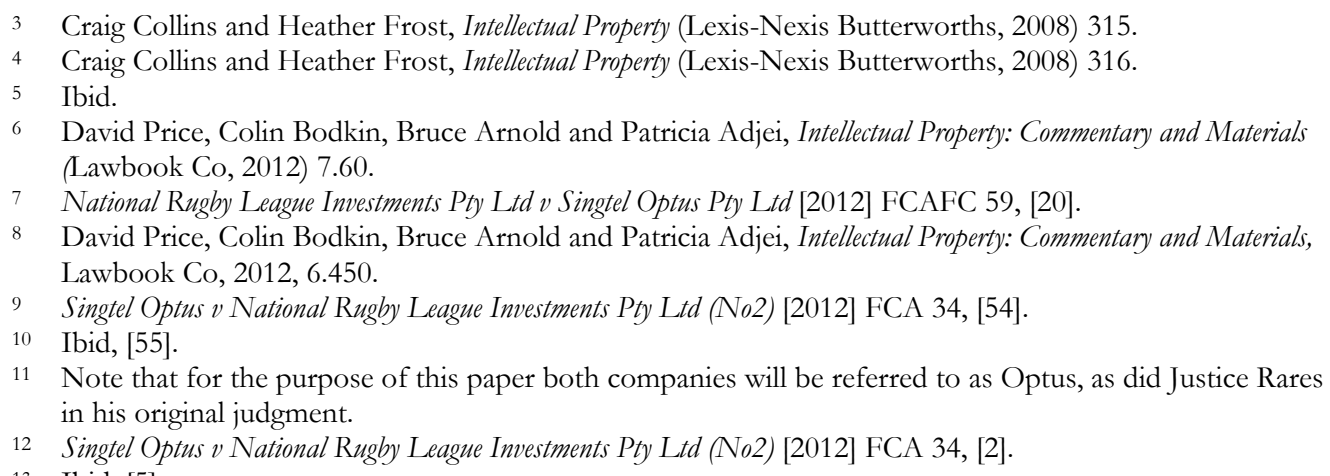


the ability of people using TV Now to record programmes, and then watch them time delayed, was in breach of the Copyright Act.

\section{Singtel Optus v NRL Investments}

In the original trial Justice Rares accepted that the NRL and AFL had exclusive rights to make cinematograph films under s 87 of the Copyright Act, and make a copy of that film, that is, reproduce a broadcast of that film under s $86 .{ }^{15}$ The issue then was whether there had been a breach of the amended s 111 which allows people to record films, or sound recordings, to watch at a more convenient time as long as it is solely for private and domestic use. The first issue then was who actually makes the copy under the services provided by TV Now - the individual user, for private domestic purposes, or Optus, for commercial use. Justice Rares was of the opinion that it was the user, whenever "he or she clicks on the "record" button on the TV Now electronic program guide. ${ }^{16}$ The reason for this was that the 'user is solely responsible for the creation of those films' and if the user does not click 'record' no films will be brought into existence that he or she can play back later.' ${ }^{17}$ It was also his Honour's opinion that it was impossible to say Optus makes any of the films when the user clicks 'record.'18

Having established who did the act of recording, the second issue was whether these recordings constituted copyright infringement. His Honour stated that the purpose of the exception in s 111 (1) and (2) was to acknowledge that copying for private and domestic use was common and permissible. Justice Rares also stated that there was no evidence to suggest that the users had any purpose other than to watch the games for their own private use. It was also his Honour's opinion that the expression 'at a time more convenient' did not preclude watching a film near live if the viewer found that to be more convenient as the 'section must be concerned with what the viewer subjectively thinks is a more convenient time for him or her.' ${ }^{19}$ His Honour then held that users 'made their films and viewed them near live solely for private and domestic purposes by watching them at a more convenient time than that of the live broadcast. ${ }^{20}$

Justice Rares ruled that it was the user who was responsible for any communication within the meaning of s $22(6)^{21}$ because they initially chose to record the program to play at a later time, even though it was Optus that provided the services. Thus, it was the user, and not Optus, who was 'the person responsible for determining the content of the communication within the meaning of s 22(6). ${ }^{22}$ His Honour then held the "communication made by the user to him or herself of the film that he or she recorded is not made "to the public", but was a communication only 'made by the person who made the recording.' ${ }^{23}$ The decision, however, was appealed to the Full Court of the Federal Court. ${ }^{24}$

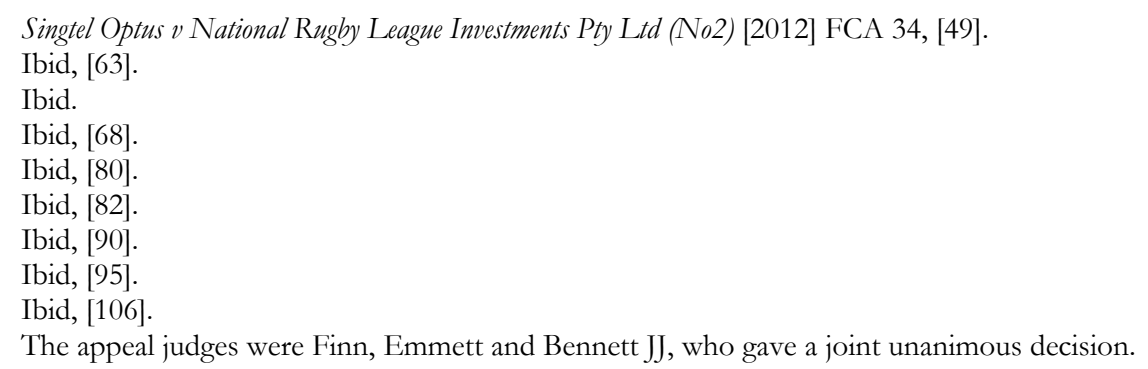




\section{National Rugby League Investments v Singtel Optus}

It was stated by the Full Court of the Federal Court that the two main issues in the appeal was who made the recording of the NRL or AFL matches, ${ }^{25}$ and if it was Optus that made the recordings, whether they could rely on the 'private and domestic use' defence. ${ }^{26}$ The NRL's appeal was on the basis appealed that Justice Rares had erred in 'approaching the maker question through s 111', in 'finding that the subscriber alone did the acts involved in making a copy', and in 'disregarding Optus' heavy involvement in the creation of the copies', and 'its responsibility for ensuring that a copy was made following a user's request. ${ }^{27}$

Their Honours held that 'the Optus-subscriber relationship was contractual in nature' which allowed subscribers to record and store television programmes for 'your own personal use.' Critically, however, it was noted that at all times Optus 'retained possession, ownership and control of the physical copies made on the hard disc of its NAS computer until they were deleted by Optus after the expiry of 30 days from recording or by the subscriber before them.' 28

The Court therefore overturned the original decision that 'the subscriber was the maker for s 101, and hence s 111, purposes. Their Honours stated that the issue was 'not simply how something is made' but 'by whom it is made. ${ }^{29}$ It was then held that:

Optus' role in the making of a copy - ie in capturing the broadcast and then embodying its images and sounds in the hard disk - is so persuasive that, even though entirely automated, it cannot be disregarded when the "person" who does the act of copying is to be identified. The system performs the very functions for which it was created by Optus. Even if one was to require volitional conduct proximate to the copying, Optus' creating and keeping in constant readiness the TV Now system would satisfy that requirement ${ }^{30} \ldots$ What Optus actually does "has a nexus sufficiently close and causal to the illegal copying that one would conclude that the machine owner...trespassed on the exclusive domain of the copyright owner." 31

The next question then was whether Optus did the act alone, or whether Optus and the subscriber 'are jointly and severally responsible for that act'.32 It was held that 'without the subscriber's involvement, nothing would be created; without Optus's involvement nothing would be copied'. ${ }^{33}$ Each cinematography film and sound recording of the broadcasts and copies of the films which were produced after a subscriber had clicked the 'record' button on the Optus device, was not made by the subscriber alone. When characterising the word 'make' under the Copyright Act, ${ }^{34}$ the Court indicated that Optus had solicited subscriber in utilization of its services and also designed and maintained a sophisticated system which could effectuate the making of recordings for time-shifting viewing. ${ }^{35}$

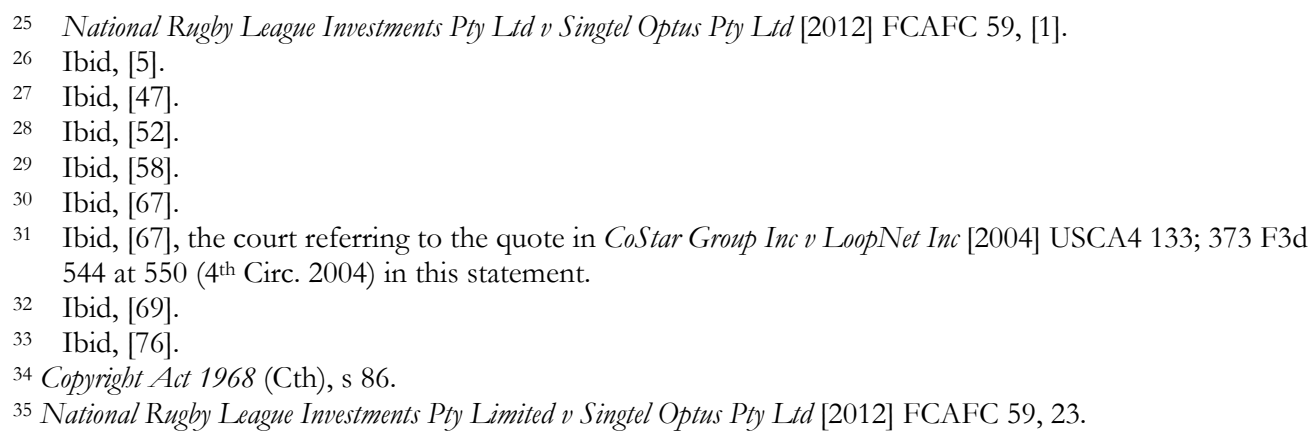


Thus, both were considered 'jointly and severally responsible for the act of making the copies.' However, it was then held that as s 111 was not intended 'to cover commercial copying on behalf of individuals ${ }^{\prime 36}$ its protection extended to individuals alone. Optus therefore was not protected by that section, and as it could be severally liable, 'it alone could be sued'. ${ }^{37}$ While the users may have been the maker of the copies, Optus was also making copies on behalf of its subscribers and this commercial service did not fall within the scope of s 111 private copying. ${ }^{38}$ According to their Honours who referred to the 2007 Explanatory Memorandum explained by the AttorneyGeneral, the defence addressed the private copying by individuals in their own homes using personal recording devices ${ }^{39}$ and there was nothing in the language of $\mathrm{s} 111$ to suggest that it was intended to cover commercial copying on behalf of the individuals. As Optus made no use itself of the copies of the broadcasts and merely stored them for 30 days, Optus could not invoke the $\mathrm{s}$ 111 exception.

Thus, the appeal by the NRL was successful, and although Optus then applied for special leave to the High Court, this was rejected. Meanwhile in Europe, legal action was being taken in regard to alleged breaches of copyright in regard to the broadcasting of EPL matches.

\section{THE ENGLISH PREMIER LEAGUE}

\section{Background facts}

The Football Association Premier League (FAPL) runs the leading professional soccer league in England, the EPL. The body is responsible for both marketing the television broadcasting rights for the matches, and the granting of licences for such rights. Exclusive live broadcasting rights are granted for the matches on a territorial basis, and since these are usually to just one Member State of the European Union (EU), television viewers are only permitted to watch matches transmitted by broadcasters in the state where they reside. To protect this territorial exclusivity each broadcaster agrees, under the terms of the licence agreement, to encrypt its satellite signal..$^{40}$

A dispute arose when a number of English pubs, rather than paying an annual commercial subscription of around $f_{2000}$ for Sky's services, ${ }^{41}$ were instead obtaining much cheaper Greek decoder cards and installing them into their set-top boxes. This then allowed them to decrypt the Greek satellite broadcaster's signal, hence enabling them to provide coverage of EPL matches to their customers at a much cheaper cost. ${ }^{42}$ The FAPL subsequently took legal action on the grounds of breach of copyright in relation to s 20 of the Copyright, Designs and Patents Act 1988 (UK) (CDPA), and its European equivalent, Article 3 (1) of the Copyright Directive (2001/29/EC). They argued that there was a breach by screening the matches to the public, without the appropriate territorial subscription.

36 Ibid, [89].

37 Ibid, [93].

38 Ibid.

39 National Rugby League Investments Pty Limited v Singtel Optus Pty Ltd [2012] FCAFC 59, 25.

40 Ike Gocmen, 'Judgment in Cases C-403/08 and C-429/08' 4 October, 2011,1.

41 Bill Batchelor and Tom Jenkins, 'FA Premier League: the Broader Implications for Copyright Licensing,' (2012) 33 European Competition Law Review 157, 163.

42 Ibid,157. 
The action joined a number of cases involving the FAPL, QC Leisure, AV Station PLC, and also pub owner, Karen Murphy. While the matter was originally heard by the England and Wales High Court (EWHC) ${ }^{43}$ a number of matters were referred to the European Court of Justice (ECJ).

\section{The European court decisions}

An opinion by EU Advocate General, Juliane Kokott, was handed down on 3 February 2011 in regard to the two cases, FAPL $v$ QC Leisure, ${ }^{44}$ and Karen Murphy v Media Protection Services Ltd. ${ }^{45}$ AG Kokott held that the exclusivity of the broadcasting rights restricted the freedom to provide services to the internal market, and partitioned internal markets into separate national markets. It was also held that under EU law there was no comprehensive right to protect communication of a public broadcast when no fee was being charged to watch it. ${ }^{46}$

The ECJ, meanwhile, delivered its decision on 6 October, 2011, stating that a licensor of copyright could not lawfully impose territorial restrictions on its licensees, and that laws preventing receiving ex-territory broadcasts were unenforceable under the EU principles of freemovement. ${ }^{47}$ While reproduction of the matches on the pub's set-boxes and televisions did not infringe copyright, the subsequent public showing of the matches was a potential infringement of copyright. ${ }^{48}$ Thus, if the pub owners or managers were only obtaining the matches for their own private, domestic use, there would have been no infringement of copyright. However, once they had taken the extra step beyond merely receiving matches for their own use and were publically showing them to entertain and attract customers, it was no longer for domestic use. There was now a further act of communication to the public of protected works which required a license, and without it, a pub owner showing the matches to customers could be in breach of FAPL's copyright. 49

Thus, while aspects of the case were decided in favour of the FAPL, its problem lay in regard to what was then deemed to constitute its 'protected rights'. The ECJ stated that the FAPL could not claim copyright in regard to the actual EPL matches. This was because they could not 'be classified as works' in regard to copyright. ${ }^{50}$ The ECJ went on to state that:

[S]porting events cannot be regarded as intellectual creations classifiable as works within the meaning of the Copyright Directive. That applies in particular to football matches, which are subject to rules of the game, leaving no room for creative freedom for the purposes of copyright. ${ }^{51}$

The ECJ, however, acknowledged that sporting events have a 'unique' and 'original' character, transforming them into subject matter capable of being protected as works. ${ }^{52}$ Certain aspects of the broadcasts were then held to be protected under copyright as 'works', namely the opening

43 Football Association Premier League Ltd v QC Leisure [2008] EWHC 2897 (Ch).

44 C-403/08.

45 C-429/08

46 EU Advocate General Opinion: Cases C-403/08 and C-429/08, Client Advisory February 2011, Edwards, Angell, Palmer \& Dodge. eapdlaw.com.

47 Football Association Premier League Ltd v QC Leisure [2012] FSR 1, [67]

48 Ibid, [182].

49 Batchelor and Jenkins, above n44, 158.

50 Football Association Premier League Ltd v QC Leisure [2012] FSR 1, [96].

51 Ibid, [98].

52 Ibid, [100]. 
video sequence, the EPL 'anthem', recorded highlights, and various graphics used in the course of the broadcasts. ${ }^{53}$

\section{The English court decisions}

After the ECJ's decision, the matter was once again heard in the EWHC, a judgment being handed down by Kitchin LJ on 3 February 2012. It was held by Lord Kitchin that the supply of the decoder cards to customers was an authorisation to use such cards for the purpose for which they were supplied, namely for publicans to allow customers to watch the television programmes in their pubs. ${ }^{54}$ Kitchin LJ then went on to state that broadcasting an actual EPL match in a pub was a communication to the public within the meaning of s 20 of the CDPA. ${ }^{55}$ His Lordship, however, held that s 72 provided a statutory exception, namely that it was being shown to 'an audience who has not paid for admission'56 though, like the ECJ, it was further held that there had been breaches of what constituted the FAPL's protected works, such as its 'anthem. 57 The requested injunction, however, was not granted on the grounds that his Lordship accepted an undertaking from the defendants not to breach the FAPL's copyright. ${ }^{58}$

In Murphy v Media Protection Services Ltd $\tilde{d}^{-9}$, publican Karen Murphy had been convicted under s 297 (1) of the CDPA of dishonestly receiving a broadcast from a place within the United Kingdom with the intention of avoiding having to make payments in relation to the charges applicable to the reception of that programme. ${ }^{60}$ However, on appeal, it was held that Murphy had 'paid for the card, had not avoided any charges applicable to its use and had not acted dishonestly. ${ }^{91} \mathrm{Her}$ conviction was overturned. ${ }^{62}$

As Marris and McGrath suggested, the decision in FAPL v QC Leisure was 'perhaps contrary to the wishes of the copyright owners'. ${ }^{63}$ It also meant that the FAPL was forced to renegotiate licencing agreements and introduce contractual prohibitions, including that licensees in Europe could no longer provide an optional English language feed. Restrictions were also placed on the number of matches that a licensee could transmit on the main game day, namely Saturday afternoon, with licensees outside of the UK being restricted to just one match. ${ }^{64}$ Thus, it was a practical, contract-related solution found to best protect the FAPL broadcast interests within the UK.

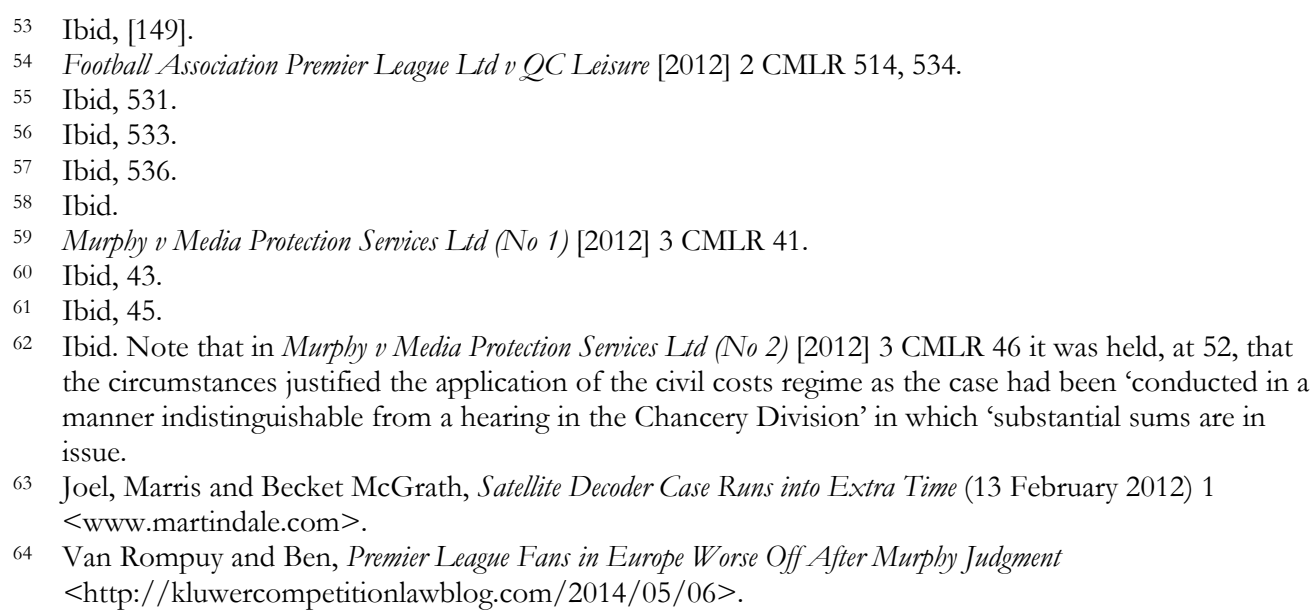


What will now be discussed is the relevant copyright law's application to sport, the importance of protecting the copyright of sports broadcasts, and whether sport is part of a larger entertainment industry.

\section{DISCUSSION}

While English soccer has been full-time professional for over a hundred years, the sale of extensive broadcast rights to Sky greatly increased the money in the game, which subsequently boosted the EPL's attraction, not only to English soccer supporters, but also to fans around the world. The practice of pub owners not paying commercial rates for showing EPL matches could, potentially, have an impact on the amount of money Sky will be willing to pay for its future television rights, just as Optus' use of the two minute delay telecast could have had an impact on Telstra's willingness to pay for on-line rights.

In Australia, however, the Full Court of the Federal Court's decision now means the NRL and AFL's ability to sell online rights for games to be shown on mobile phones remains intact. The AFL had been protected by a signed contract for a new five year deal worth $\$ 1.25 \mathrm{~b}, \$ 157 \mathrm{~m}$ of which was to allow Telstra the right to show the games on mobile phones. In the meantime, the NRL was in the process of negotiating its new television deal, and therefore could have been hampered in the short term by the reluctance of any company to pay for these mobile phone rights. The long term ramifications for both leagues could have been far worse, however, had the decision gone against them. While the amount paid for these on-line rights is relatively small, if Optus, or any other mobile phone company, was able to provide coverage of the games on a two minute delay, the value of the overall television rights could well have been devalued, perhaps even to the point of placing in jeopardy the ability of both competitions to remain full-time professional.

As the case progressed, there were calls for the Copyright Act to be yet again amended, with there being strong criticism of the 2006 amendments. ${ }^{65}$ However, despite their relatively recent introduction, these amendments did not envisage technology that would provide the service that Optus was able to provide for its customers in the form of the two minute delayed coverage of football matches. However, rather than this being seen as an indication of the inadequate nature of s 111, what it really highlights is that the Copyright Act is, and always will be, susceptible to future technologies. Thus, one broader outcome of the Federal Court's decision was that there was no immediate need for further, potentially quite urgent, amendments to the Copyright Act.

While Australian copyright law has closely followed the English law, it is suggested that the recent sport cases in both countries highlight a significant difference. It was agreed in NRL $v$ Optus that the copyright in the AFL and NRL matches lay with the relevant governing bodies. However, in FAPL $\vee$ QC Leisure the FAPL did not successfully claim copyright in the actual EPL matches. It is also important to recognise the practical difference between the two decisions. Once the NRL obtained a judgment stating that Optus was in breach of copyright, it then meant future breaches were immediately prevented since Optus could no longer broadcast the games to its mobile phone users, at least not without being in clear breach of the law. The FAPL's further problem, on top of the limited scope of its copyright, is the enforcement of what copyright it actually holds. This is because it was not a breach to have the decoders in the first place, nor was it copyright infringement to show the actual matches; only the aspects which fall under the FAPL's protected works, such as its anthem. This indicates that while the FAPL can still take legal action

65 Glenda Korporaal, 'Footy In A Losing Position', The Australian (3 February 2012) 13. 
for copyright infringement, it will need to be filed against each individual pub owner, and FAPL will bear the factually difficult burden of proving a breach of its limited copyright.

Another question that arises in NRL $v$ Optus is whether sport in Australia is unavoidably part of an overall entertainment industry, or remains as a separate industry in its own right. The proceedings were marked as 'yet another round in what has been described as the conflict between the electronic equipment industry and the entertainment industry. ${ }^{66}$ The trial judge, Justice Rares, had earlier referred to CBS Songs Ltd v Amstrad Consumer Electronics Plo ${ }^{67}$ in stating that there was a 'somewhat symbiotic love-hate relationship between the entertainment industry, the electronics and communications industries and the consuming public.' 68 His Honour then pointed out there was ongoing conflict between the entertainment industry's ('of which the AFL and NRL are part') desire to maintain exclusive rights over its output, and the electronics and communications industries' wish to sell their products and services so that the public can see, hear and copy what the entertainment industry was exploiting. ${ }^{69}$

Thus, the court in NRL $v$ Optus acknowledged that it was another case involving the conflict between copyright holders and those wishing to exploit it in order to sell their own products. There are express statements that, within Australia at least, sport is part of a broader entertainment industry. This is perhaps understandable, given the nature of copyright and context in which it arises. It should also be noted that in News Ltd v Australian Rugby League ${ }^{70}$ - a case that involved litigation arising from the formation of Super League, similar conclusions were reached in regard to the issue of markets. ${ }^{71}$ This likewise supports the view that sport within Australia is part of a larger entertainment industry.

\section{CONCLUSION}

Despite copyright being an area of law with a strong international flavour, the recent copyright infringement cases that involved professional sporting leagues in both Australia and England produced significantly different outcomes. The decision in FAPL $\vee$ QC Leisure indicates that the FAPL's copyright is limited to areas such as its anthem, rather than the matches themselves. By contrast, in Australia courts have considered the broadcast of the sporting match itself to be covered by copyright principles, in the context of the 2006 amendments to the Copyright Act. These enactments (amendments?) had been made for a specific purpose: namely to allow people to legally make recordings and then watch or listen to the original broadcast at a more convenient time. This is the position regardless of the extent of the delay between the original broadcast and the point at which the recording is consumed. As long as this had minimal impact on the market, it was a common sense approach to allow people to legally make good use of the available technology.

NRL $v$ Optus has highlighted a potential problem in the legislation where, in regard to sports broadcasts, the amendments could have a significant impact on the relevant market. The Full

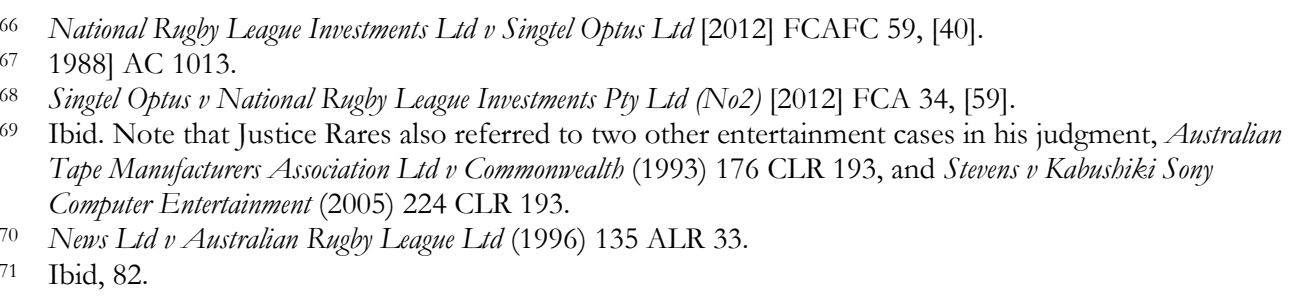


Court of the Federal Court's interpretation of the relevant sections of the Copyright Act, however, has ensured that the copyright owners of sports broadcasts remain protected without any further amendments to the Copyright Act. Finally, there are statements in NRL v Optus confirming that sport should be considered a part of the larger entertainment industry in Australia. 